\title{
Reading the Parable of the Rich Barn-Builder (Luke 12:13-21) in the Context of the Problem of Materialism in Contemporary Nigerian Christianity
}

\author{
OmakaKaluNgele (Ph.D), ${ }^{1}$ Kingsley Ikechukwu Uwaegbute ${ }^{2}$ \\ (corresponding author) and Damian Onyemaechi Odo ${ }^{3}$
}

\section{Abstract}

The quest for material possessions has become a dilemma in contemporary Nigerian Christianity. This research therefore focuses on interpreting the parable of the Rich Barn-Builder in Luke 12:13-21 in the context of materialistic view of Christianity in Nigeria. Elements of diachronic method of exegesis was applied to this effect and it was found out that the parable of the Rich Barn-Builder in Luke condemns, in the most strongest terms, covetousness which manifests in quest for earthly/material possessions which, in turn, runs contrary to interest in God. In this regard, the research showed that the teachings of this parable warn Nigerian Christians about the danger in seeking material possessions as an end in itself or, for selfish purposes at the expense of interest in God and, the use of wealth in the service of humanity. The research therefore recommends for strong de-emphasis on the view that material possessions are a manifestation God's salvation which has become a dominant ground on which contemporary Nigerian Christianity grows.

Key Words Covetousness; Luke 12:13-21; Nigerian Christianity; Materialism, Rich Barn-Builder

\section{Introduction}

The gospel of Luke is well-known to have preserved a lot of material on the teachings of Jesus which are not found in other gospels. One of these peculiar Jesus' teachings is the parable of the Rich Barn-Builder recorded in Luke 12:13-21. Although not very memorable like other peculiar Lukan parables, ${ }^{4}$ the parable of the Rich Barn-Builder teaches important lesson on a dominant theme which runs

1 Omaka Kalu Ngele (Ph.D) teaches New Testament studies both to undergraduate and postgraduate students in the Department of Religion and Cultural Studies, University of Nigeria, Nsukka. He can be contacted at omaka.ngele@unn.edu.ng

2 Kingsley Ikechukwu Uwaegbute teaches New Testament studies in the Department of Religion and Cultural Studies, University of Nigeria, Nsukka. He can be contacted at kingsley.uwaegbute@unn.edu. ng. He is the corresponding author of this article.

3 3Damian Onyemaechi Odo teaches Old Testament studies in the Department of Religion and Cultural Studies, University of Nigeria, Nsukka. He can be contacted at damian.odo@unn.edu.ng.

4 Two most memorable parables in Luke are parables of the Good Samaritan and The Prodigal Son. 
through the gospel of Luke. This dominant theme, as De Silva (2004) rightly called attention to, is the issue of Christians and the proper use of wealth.

Properly understood, the parable of the Rich Barn-Builder in Luke draws Christians' attention to the futility of amassing earthly/material possessions which, definitely, sways proper dedication to God.Karris(2000:704) is right in saying that this parable 'warns the disciples about the futility of seeking refuge from opposition by amassing wealth.' On this premise, this parable is one of Lukanpericope in which materialism/earthly possession is strongly discouraged by Jesus since it negatively affects dedication to God.

The very danger which materialism and excessive desire for earthly possessions pose for Christians, as the parable of the Rich Barn-Builder warns, has become common place in contemporary Nigerian Christianity. Without doubt, Nigerian Christianity has grown over the years. If we are to use numeric strength and multiplication of church buildings as yardsticks of measuring the growth of present day Nigerian Christianity, then it is very safe to say that Nigerian Christianity has indeed grown to an enviable height.

Commenting on this, Aweda (2009:1) wrote that 'every street and corner of all our big cities, villages and hamlets are full of churches, services are full to capacity, some running three or more session.' However, there is no denying the fact that contemporary Nigerian Christianity grows, in part, along materialistic lines. In other words, contemporary Nigerian Christianity is marred with materialistic view of the Christian practice. With the emergency of Pentecostalism in Nigerian Christianity during the 1970 s and its subsequent explosion during the $1990 \mathrm{~s}$, ${ }^{5} \mathrm{ma}-$ terialistic view of Christianity became on the increase. In fact, within the Pentecostal circles, materialism/quest for material wealth has become the ground on which Christian teachings thrive. This has also affected the mainline churches to the extent that members and church leaders alike are all enmeshed in quest for material possessions.

All these led Egbujo (2015) to assert that 'materialism, opportunism and vain glory have taken front pairs and chased spirituality to the back benches, and that is trouble. Pre-occupation with prosperity and instantaneous gratifications have left no air for the Nigerian church to breath.'

Although the above-painted picture resonates well with African expression of Christianity in which worldly possessions are believed to be synonymous with the Christian practice (Kalu in Ngong 2009), there is a great need to address this sham in contemporary Nigerian Christianity from strong biblical view point. Therefore,

5 E.N. Onwu "Poverty and Prosperity in Nigeria Pentecostal Theology: A New Testament critique" Journal of New Testament Research, Vol.I (2006) 
the task before this research is to address the problem of materialism which has plagued Nigerian Christianity from the view point of the parable of the Rich Barnbuilder in Luke. The research also aims at discerning what lessons Nigerian Christians can learn from the parable.

In terms of methodology, the research adopted, firstly, textual critical method since the text of the parable has textual problem in its original Greek. Secondly, the research makes use of elements of both source and form criticisms. On the whole, the methodology applied in the research can be referred to as having elements of diachronic method of exegesis(Gorman 2006).

\section{Setting the Scene: Source, literary devices, "Sitz im Leben" and contexts of the parable of the Rich Barn-Builder in Luke 12:13-21}

\subsection{Source of the parable}

Among other goals of biblical criticism which gathered momentum from the 19th century upwards, is to find the source(s) behind the gospels. The goal to determine the sources (oral/written) behind the gospels is called source criticism. This is the point Chinwokwu (2015:31) makes when he avers that source criticism 'ask the question: what written sources might the author of a Gospel have used?' Critical studies by scholars over the centuries have actually yielded positive result as regards the sources behind the gospels, especially, the synoptic gospels. Though there are many hypotheses of the possible sources of the gospels, it seems the most accepted is the four source theory which is otherwise called Markan priority.

As contended by Streeter in 1924, there are four possible sources behind the synoptic gospels. These include Q (Quelle) which is German name for source which contained sayings of Jesus presumed lost, Mathew, Luke, 'M' (special Mathean material) and 'L' (special Lukan material). The interest of the researchers is on the 'L' (special Lukan material/source). The 'L' source as Chinwokwu (2015:28) has argued 'may have been written down before hand or may be oral stories that the author himself heard.'However, it is safer to assume that since Luke was a companion of Paul, the 'L' source may have been a product of the traditions about Jesus which Luke heard in Jerusalem or Caesarea where it has been assumed the gospel was composed. On the issue of the locale or community of Luke, however, we must note that it is still an on-going debate among scholars. The 'L' source, the researcher agrees with Bultmann(1963) and Chiwokwu(2015), contains both narratives and teachings. According to Brown (2014), about $40 \%$ of the material found in Luke is contained in the ' $\mathrm{L}$ ' source. Of particular interest to the research is the fact that the teachings contained in the ' $L$ ' source include fourteen parables which are particularly Lukan. The parable of the Rich Barn-Builder is among these fourteen parables 
which the gospel of Luke alone preserves. In this regard, the parable of the Rich Barn-Builder is adjudged to be an authentic product of the 'L' source which makes the gospel of Luke distinctively Luke.

\subsection{Literary Devices in the Parable of the Rich Barn-Builder (Luke 12:13-21)}

Johnson (2009) is absolutely right in saying that Luke, the assumed writer of the gospel of Luke was a literary genius. If not for anything, the use of parable as a literary device in Luke is most outstanding. As has been pointed out, Luke added fourteen parables to his Markan source which is an indication of his use of parable as a literary device. The text for study, which is Luke 12:13-21 is a parable. According to Alland(1993) a parable is a proverb or a symbol. Chinwokwu (2015:171) more elaborately, says that a parable is 'a simple brief story of an episode that may or may not have actually taken place but speaks in familiar and life-like terms to the listener and conveys some special truth of significance to life.'The use of parable as a teaching method predates both Jesus and Luke. In the Old Testament and later rabbinic Judaism, parables were already as employed as a teaching method. A parable in Hebrew is called $m \bar{a} \breve{s} h \bar{a} l$ ( $m \bar{e} s ̌ h a l i m$ for plural). In the Old Testament, parable is an extremely fluid form of wisdom saying which basically includes short proverbs (e.g. 1 Sam 10:12), metaphors (e.g. of Ez 17:21-24), allegories, cajolesongs/riddles (e.g. of Mic 2:4), by words of reproach and prophetic proclamations (Num 23:7,18). As found out by Gowler (2006) the contexts of usages of parables in rabbinic Judaism shows that they were used by rabbis when delivering sermons in the synagogues and studying the Torah in the academies. Parables in rabbinic Judaism are usually enigmatic sayings and images that puzzle and challenge hearers.

Hence, in rabbinic Judaism, parables were usually not clear illustrations. Rather, they were told to make the listener find the meaning of such parables for himself. The rabbis who held sway in rabbinic Judaism usually had parables aimed at impacting religious/moral truths. In this regard, Jewish parables were created for edifying/moral purposes: hence, they were moral in character. Luke took up the use of parable as a teaching method employed by Jesus and, applies it as a literary device which helped him put across some of his theological positions. Parable usages in Luke by Jesus, we must add, covers a wide range of sayings and images as pointed out above. The parable of the Rich Barn-builder in Luke 12:13-21 is one of the parables strictly employed by Luke to help him put across his theological positions concerning Christians and the problem of wealth/materialism.

\subsection{The Sitz im Leben of Luke 13:21-31}

The phrase sitz im leben is of German origin and translates as 'situation in life'. It denotes the "historical and sociological dimension of form criticism which calls 
attention to vital connection between literary forms and the structures and institutions which scholars discerned in working with biblical texts and their total cultural background (Chinwokwu 2015:3)'In other words, sitz im leben calls attention to the real-life situation of the early Christian community (church) which guided the formulation and writing of the gospel tradition.

Form critics like Schmidt (1919),Debelius $(1934)^{6}$, Bultmann (1963) and Taylor(1934) have all contended, in many ways, that the practical needs of the early church were catechetical, liturgical, instructional, apologetic and controversial. These were therefore the chief criteria that governed the selection and arrangement of the traditions of Jesus by each synoptic gospel writer which existed, and was circulated in independent oral forms. The forms which these traditions of Jesus took included pronouncement stories, miracle stories, stories about Christ and the sayings of Jesus. As widely done in form criticism, the first task is usually to identify the form which a gospel tradition took. Then, this form is assigned a Sitz im Leben that created such a form (gospel tradition). This having been said, the parable of the Rich Barn-Builder in Luke 12:13-21 belongs to the form called the sayings of Jesus. The sayings of Jesus are further classified into: (i) Logia (wisdom sayings); (ii) Prophetic and apocalyptic sayings ; (iii) Legal sayings/ community rules ; (iv)The "I" sayings of Jesus and (v)The parables (Bultmann 1963).

The parable of the Rich Barn-Builder belongs to the parabolic class of the sayings of Jesus. There is need to say that assigning a particular Sitz im Leben to individual forms of the traditions of Jesus has not always been successful.

This notwithstanding, there is every reason for the researchers to believe that the sayings of Jesus were created out of the preaching and teaching needs of the early church. Bultmann's(1963) analysis of the sayings of Jesus points to the direction of these sayings being created by the early church from the need for preaching and teaching.

We believe that the sayings of Jesus were the product of the preaching and teaching needs of the early church. This become right when considered in line with the assumption that the issue of wealth and its misuse was probably a problem confronting both Lukan community and the Gentile audience of Luke which was part of the Judeo-Roman world of First -Century AD.

The reason for the above belief is based on the fact that Luke, more than any other gospel writer, showed more interest in issues concerning the poor and use/sharing of wealth (earthly possessions) in service of humanity and God. These ideas resonate well in Luke's passages like 12:22 especially verses 33-34, 4:18, 16:19-31. Equally, Luke being a Gentile gospel writer, may be tackling the problem of amassing earthly possessions which was evident in the Judeo-Roman world of his time especially in Je-

${ }^{6}$ Debelius seemed to have been a staunch defender of the theory that situation in life of the early church influenced the forms that the gospel traditions took. 
rusalem and Caesarea where it has been suggested Luke composed his gospel(1969). The existence of the problem of wealth and its judicious use in the Judeo-Roman world of Luke and his community is attested by Lukan scholars like Esler (1987), Pilgrim(1981) and Johnson(1981) who suggest the probability of Luke using some of the teaching of Jesus in his gospel to address these problem. In this regard therefore, the researchers believe that the parable of the Rich-Barn Builder was probably a product of the preaching and teaching of the early church to which Luke belonged.

\subsection{The Literary Contexts of the Parable of the Rich Barn-Builder}

Here, both the remote and immediate literary contexts of the parable are to be discussed. By extension, the pericope to which the parable belongs is 12:1-11 which teaches about hypocrisy and the fear of God. In this pericope, Luke sets Jesus' teaching as being directed to a crowd of people. In Luke 12:1, it is made clear that a great multitude came to hear Jesus teach. Hence, the teaching of Jesus in Luke 12:1-12 was a build-up to the parable of the Rich Barn-Builder. As such, it forms the remote literary context of the parable.

The immediate literary context of the parable, that is, what immediately prompted Jesus' telling of this parable, was the request a member of the crowd-hearers of Jesus made. This request, which begins in vs 13 , tried to make Jesus intervene in sharing of an inheritance between two brothers. This request therefore prompted Jesus' telling of the parable of the Rich Barn-Builder.

\section{Exegesis and Critical Commentary on the Parable of the Rich Barn-Builder in Luke 12:13-21}

\subsection{The Text in Greek}

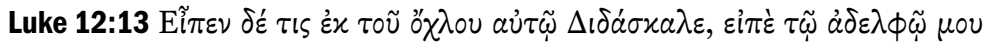

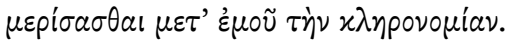

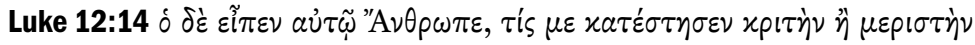
ध่ф' ن́ $\mu \tilde{a} s ;$

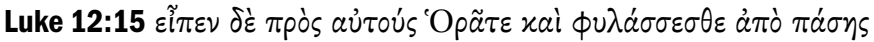

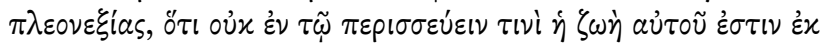

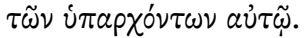

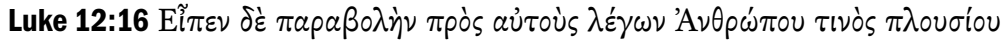

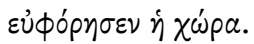

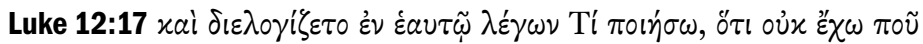

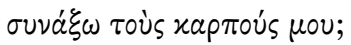

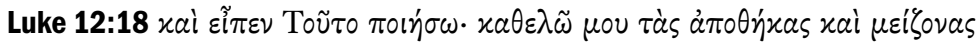

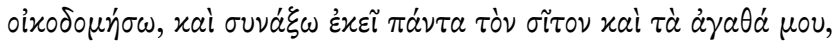




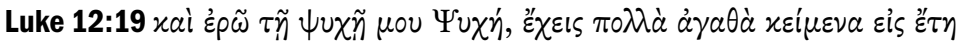

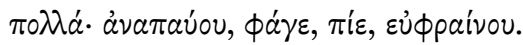

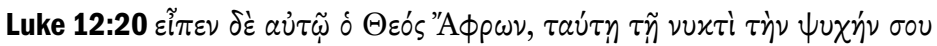

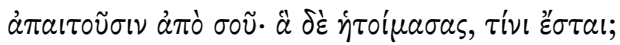

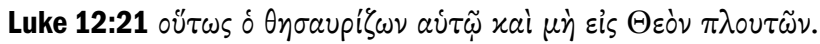

3.2 The researchers' Translation

Luke 12:13 And someone from the crowd said to Him, Teacher, tell my brother to divide the [family] inheritance with me.

Luke 12:14 But He said to him, Man, who appointed me a judge or arbiter over you?

Luke 12:15And he said to them, Take heed, and beware of covetousness: for life does not consist of in the abundance of the things which he possesses.

Luke 12:16 And He told them a parable, saying, The land of a certain rich man was very productive.

Luke 12:17 And he reasoned to himself, saying, 'What shall I do, since I have no place to store my crops?'

Luke 12:18 And he said; This is what I will do: I will tear down my barns and build larger ones, and there I will store all my crops/grains and my goods.

Luke 12:19 And I will say to my soul, Soul, you have many goods laid up for many years to come; take your ease, eat, drink, be merry.

Luke 12:20 But God said to him, 'You fool. This night your soul is required from you; and who will own what you have prepared?'

Luke 12:21"So is he who lays up treasure for himself, and is not rich toward God.

3.3 Solving Textual Problem in Vs 14 and Vs 21

The text for study has textual problems in its original Greek Text. Vs 14 of the text reads:

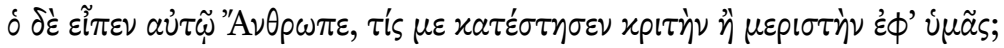

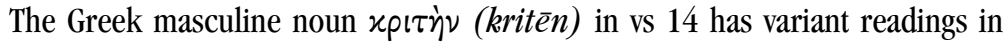

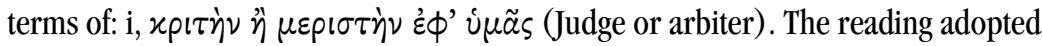

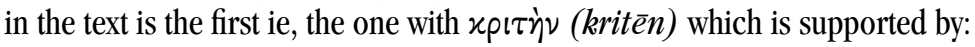

(i) P75 which is a papyrus document of early 3rd century. It contains only the gospels. Being a papyrus document, of course, makes it more closely to the original writing;

(ii) $\aleph$ and B; These are codices Sinaiticus and Vaticanus respectively. They are dated 4th century respectively. Codex Sinaiticus contains the Gospels, Acts, General Epistle, Pauline Epistle and r/evaluation. Codex Vaticanus contains the Gospels, Acts, General Epistles and Pauline Epistles. In terms of character and date of these manuscripts, they are highly reliable. Other support of these readings includes (L) which is Codex Paris of 8th century. It is also supported by f1, f13 and muscles like 33, 205, 579, 700, 892 etc. 
(iii)dikasthnh $\ddot{\eta} \mu \varepsilon \rho \vdash \sigma \tau \grave{\eta} \nu$ (Judge or arbiter): This reading is supported by; (i) A - Codex Alexandrinus of about 5th century. It contains the gospels, Acts, General Epistles\Pauline Epistles and Revelation. Although Codex Alexandrinus is a good manuscript, its support is not always regarded as being strong in textual criticism.

(ii) W - Washington manuscript of about 4/5th centuries AD. It contains only the Gospels. Perhaps as widely said in textual criticism, Washington codex is more interesting than reliable. This means that its character support is not always strong as long as textual criticism is concerned.

(iii) $\Delta, \theta, \psi$ : These are St Gaul, Tbilisi and Athos Codices. But for Athos $(\psi)$ which contains the Gospel, Acts, General Epistles and Pauline Epistles, St. Gaul and Tbilisi contain only the Gospels. They are dated 9th and 10th centuries respectively. Their witness support, based on date and reliability, is not to be highly relied upon.

In Vs 21 , we meet a different and intricate textual problem in forms of addition and omission from an original Greek text. In other words, $v 21$ of the text is omitted in some ancient manuscripts. While $\mathrm{P} 45, \mathrm{P} 75$ which are Papyrus documents of 3rd century and codices like: (Sinaitcus) A (Alexandrinus), B (Vaticanus) L (Paris) etc adds vs 21 other ancient manuscripts omit it entirely. This is seen in the 3rd variant reading in the footnote of the Greek text of Luke 12:13-21. However, it is only manuscript like D (Bezae Cantabrigiensis) that omits the text entirely. This manuscript is of 8th century date and does not really provide reliable witness in most cases.The other variant (2) retains the verse with the addition of tauta legwn efwnei. This variant is supported by f13 and minuscule like $180,579,597,1243$, etc. It is however interesting to note that none of the minuscule in existence dates before 9th century. This means that they are of late origin and as such cannot be relied upon as important witnesses.

\subsection{Adopting reading for Exegesis}

In the case of vs. 14, the researchers adopt the first reading adopted in the text. Based on date and character support of the witnesses it has, it is deservedly so for the reading to be adopted. This means that the researchers adopt the reading that has $x \rho i \tau \dot{\eta} \nu \ddot{\eta} \mu \varepsilon \rho เ \sigma \tau \dot{\eta} \nu$.

In vs 21 , the researchers adopt the reading retained in the text. Being supported by papyrus documents and heavyweight manuscripts like Codex Sinaiticus, Vaticanus and Alexandrinus all makes for its adoption here for exegesis.

\subsection{The Literary structure of the Text}

The parable of the rich barn-builder by the researchers' structure is made up of three sub-components which are linked together by conjunction likedev can translate as 'and' or,'but'respectively. Verse 13 which begins the pericope is a component of its own and, it introduces the questioner from the crowd who wanted 
Jesus' intervention in sharing an inheritance. Verse 14 also is a component of its own; it deals with Jesus' objection to sharing an inheritance as demanded by the questioner from the crowd. The third component begins from verse 16 which deals with the rich barn-builder's attitude to material possession. All these components were cleverly woven together by Luke in other to achieve a kind of building-up of Jesus' teaching in the periscope; for example, the questioner from the crowd leads to Jesus' refusal to share such an inheritance based on the ground that it is what covetousness entails. Luke then had Jesus tell the parable of the rich barn-builder which is the third component of the pericope beginning from verse 16 .

\subsection{Reading the Text Closely}

\section{Vs 13: A Member of the Crowd Asks for Jesus' Intervention in the Shar- ing of an Inberitance}

It had been noted that the remote literary context of this parable is Luke 12:1-12. In this narrative, the multitude had already gathered around Jesus to hear him teach. After his teaching on the fear of God and confessing him (Christ) before men, an unidentified member of the crowd appealed for Jesus' help in sharing an inheritance which he had with his brother. This is akin to the incident in 1Kings 3:4-28 whereby King Solomon was asked to be an arbiter on an issue involving two women claiming ownership of a baby. According to Moorman (1961) Jesus had proclaimed himself to be a 'better Solomon' and as such, a member of the crowd thought that such a better Solomon must have the power to arbitrate on the issue of dividing the inheritance he had together with his brother. Probably, Jesus must have known about what trouble Moses got himself into in Exod 2: 14 when he tried to intervene in the case of two Jewish brothers who were fighting. Besides, it is clear here that Jesus probably did not know the said inheritance or the brother with whom the inheritance was to be shared.

\section{Vs14 -15:Jesus objects to sharing an unknown inberitance}

Here we see clearly Jesus' objection to the request of a member of the crowd who had wanted him intervene in the division of their inheritance is clearly seen. The vocative "A $\nu \rho \omega \pi \varepsilon$ (anthrope) (man) is a case of direct third person address by Jesus. It is in response to the request for himto be an arbiter over an inheritance.

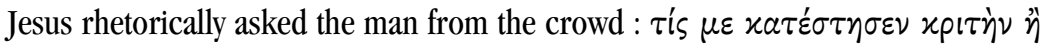

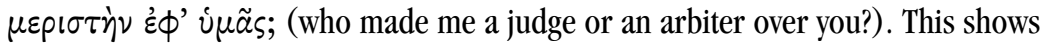
Jesus' intention not to meddle with issues of dividing an inheritance between two brothers.

His refusal must be understood in the context of preceding verse (15) in which he warns, strictly, about covetousness which leads to excessive desire for earthly

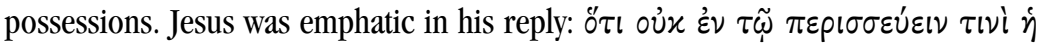




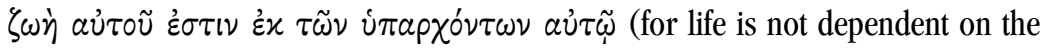
possessions one has). The key word here is i $\pi a p \chi o ́ v \tau \omega \nu$ (buparchoutōn) which is a verb and the participle active genitive neuter form of $\dot{\tau} \pi \alpha \rho \chi \omega$ (buparchō). It means possessions which, of course, refer to earthly/material things one has. This is a startling and disappointing reply for the questioner from the crowd who had expected Jesus to intervene in equal division of an inheritance. To Jesus, the questioner from the crowd was covetous since his only interest was on material possessions he had jointly with his said brother. But Jesus' mission was not channeled to this effect. Porter(1988:1208) is indeed very correct in saying that Jesus 'mission was not to settle the differences which brothers, joint-heirs moreover of the covenant, ought easily to have to have composed themselves.' In this regard therefore, Jesus did not come to handle dispute such as the ones the questioner from the crowd was demanding from him.

\section{Vs 16-21: The Barn-Builder's attitude to Material Possession}

To further buttress the needless care for worldly possessions which the questioner from the crowd exhibited, Jesus tells the crowd a parable- a parable about a rich barn-builder. In this parable, Jesus relates how the ground/farm of a certain man yielded plentifully. This was why the man asked himself what he should do with all his crops and goods. His best thought was to pull down his old barn and build a much larger one. In this much bigger barn, the barn-builder hoped to store all his crops for future use. At this, the barn-builder said to himself that he will from thence live a life of merriment since he had store-up enough crops and goods to last many years. However, at this thought, came the barn builder's greatest misfortune for his met with an untimely death. According to this parable, God addressed him as 'you fool'. Fool in the context of its usage here is written a $\phi \rho \omega \nu$ (aphrōn).Aphrōn equally means an ignorant person in classical Greek usage. Not only that the barnbuilder was called a fool, but his soul was required of him by God that very night he had thought about living a life of merriment after he had stored enough crops and goods in his larger barn.

At this (i.e his death) the question rightly understood is: $\alpha \dot{\delta} \delta \dot{\varepsilon} \dot{\eta} \tau o i ́ f a \sigma a \varsigma, \tau i \nu$ เ है $\sigma \tau \alpha$; (ba de hêtoimasas, tini estai (who will own what you have prepared?) This is a rhetorical question which Jesus asked and, also expected his hearers to ask themselves this same important question in the event of death. Jesus then ended this parable by saying that those who lay treasure for themselves here on earth have the same fate as the barn-builder because they are not rich towards God. This parable teaches great truth about earthly possessions and the peril of wealth and how these are stumbling blocks to dedication to God. Chinwokwu (2015:190) has drawn attention to the fact that "the surprising criticism made against him (the barn-builder) is simply that he kept the additional goods for himself and did not 
use them to be rich towards God.' Being rich towards God may have different interpretations. In the context of this research, it is deduced to mean dedication to God; that is, things that uplift God and are godly in principle. This is sharply contrasted with attachment to earthly possessions especially when they are not used rightly to the benefit of God and humanity. In the case of the barn-builder, Isaak (2006:1255) is indeed very right in saying that 'he is completely self-centered, separated from God and others by his love for earthly possessions.

The barn-builder falsely assumes that human life can be measured and secured with wealth. This was one of the barn-builder's greatest mistakes. Earthly possessions the barn-builder failed to understand run contrary to interest in God. This is exactly the point Brown(2014:246) makes when he writes that '.. . to enlarge a growing business, understandable in themselves, run against the contention that a strong interest in material possessions is not reconcilable with interest in God.'

The eschatological aspect of the parable cannot also be brushed aside. Jeremias(1966:130) was right in saying that the parable of the Rich Barn-Builder is an eschatological parable whose conclusion Jesus expected his hearers to apply to their own situations.This is a fact that this parable teaches, especially, with its mention about how the barn-builder's life was cut short when he thought he had secured his life with material possession.This parable therefore warns, as Brown (2014:246) puts it, of 'the individual expectation of an individual judgment taking place before the general judgment at the end of the world. The parable therefore warns of the possibility of unexpected judgment upon individuals who least expected it.' Although generally speaking, Luke is not noted for being so much interested in eschatology especially, as it relates to the end of age/world (aeon/kosmos) as notably seen in the gospel of Matthew. This parable is therefore a key to the heart of Lukan eschatology which is very much individualistic and also, rests on individual judgment by God. This individual judgment also resonates well with other Lukan parable like the Dives and Lazarus (Lk 16:19-31) where the Dives and Lazarus were judged individually by God on their time of death. Hence, the parable of the Rich Barn-Builder also deals with Lukan view of eschatology which is based on individual and independent judgment God executes on people at time of death. Therefore we see in this parable the fact that to Luke, even in the midst of wealth and earthly securities, this individual judgment can come; hence the parable points to the fact that all Christians should be careful in how they live their lives without interest in God and humanity.

\subsection{Conclusion of Exegesis and Theological thrust of the Parable of the Rich}

Barn-builder (Luke 12:13-21)

The parable of the rich Barn-Builder warns against covetousness in form of care for material things/possessions. This is because interest in material possessions runs 
contrary to interest in God. As such, they (material possessions) take one's interest in God away and replace it with interest in earthly possessions which is delusionary and self-centred since these cannot secure the human life. In other words, human security is to be found in being rich towards God through strict detachment from earthly possessions.

\section{The Problem of Materialism in Contemporary Nigerian Christi- anity}

The rate at which material possessions are being sought after in contemporary Nigerian Christianity is alarming. In fact, it seems that the quest for material possessions has become, to a big extent, synonymous with contemporary Nigerian Christianity. Though this problem has been tied with the explosion of Pentecostalism in Nigerian Christianity over the decades, it remains a hydra-headed problem bedeviling true Christian practice in Nigeria. The researchers agree with Nwadialor and Umeanolue(2013) that 'the menace of materialism in contemporary Christian churches in Nigeria has become so fertile that most pastors and ministers of the churches preach prosperity as part of spiritual salvation'. Since Christians are part of churches which make up Nigerian Christianity, the above view remains on point. Materialism which is synonymous with inordinate quest for earthly possessions by Nigerian Christians has become worrisome. This becomes a fact since, as has already pointed out, this inordinate emphasis on material possessions in Nigerian Christianity is the product of some preachers of material salvation which is waxing strong as days go by. Starting from the 1990s, which is the mostly agreed by scholars that Pentecostal explosion in Nigerian Christianity began to be felt strongly, the problem of materialism has always been on the increase in Nigerian Christianity.

Obiora's(1998) influential work had early enough focused on the problems of Pentecostalism, proliferation of churches and the attendant problem of materialism in Nigerian Christianity. Obiora called attention to the fact that the problem of materialism, especially among the Pentecostals, has led to commercialization of the Christian religion for selfish material benefits and interests. This relates to Arinze's (2014) view that quest for materialism and high-level corruption have become an issue in Nigerian Christianity.

Similarly Egbujo(2015) is indeed right in saying that Nigerian Christianity has become one in which the church embraced worldly estimations of success rather than heavenly matrices. So spirituality suffered while prosperity took pride of the place. These are what practical findings $f$ the researchers reveal in present Nigerian Christianity of present.

However, we must add that although the problem of materialistic view of Christianity seems more pronounced among the Pentecostal circles, this problem is also 
seen among the mainline churches in Nigeria today which has a direct link with the example influence of Pentecostalism in Nigerian Christianity. Among the Catholics in Nigeria, for example, Achunike (2004) has provided an in-depth discussion on the influence of Pentecostalism on Catholic priests. One of the negative effects of Pentecostalism on some Catholic priests as Achunike (2004) contended is on the area of quest for material possessions. This is also the situation in some other mainline churches in which materialistic view of Christianity has become a problem.

But, it does not make for a scholarly enquiry if we only discuss the problem of materialism without looking at some of its possible causes in Nigerian Christianity today. Some of these causes, which had been discussed elsewhere, ${ }^{7}$ include poverty, influence of primal world-views, the challenge of the centrality of the cross, the problem of proliferation of churches and modernity. These variables, critically speaking, are some of the most contributory causes of why materialistic view of Christianity presently soars high in Nigeria.

Our analysis here shows that the issue of materialism, which is a sham, has become a huge problem in contemporary Nigerian Christianity. This is because, the problem of materialism in contemporary Christianity in Nigeria has really dealt a serious blow to true spirituality and dedication to things of God which are the hall mark of true Christianity.In Nigerian Christianity today, a lot of Christians worship God not necessarily because of who God is but, on the basis of what material gains that can be obtained from such worship. This has also led to amassing of wealth by some church leaders at the expense of the poor members of the church who are mostly deceived by the misquoted and misapplied maxims like "God loves a cheerful giver" and "Givers never lack". This problem is best captured by the words of Nweke in Minchakpu (1999) when he observed that before our very eyes, bishops plunder church coffers, alter accounts, and milk our gullible simple-hearted brethren.

It is therefore in this regard that, discussed below, are some lessons Nigerian Christian should draw from the parable of the Rich Barn-Builder in Luke 12:21-31.

\section{Lessons of the Parable of the Rich Barn-Builder}

i. Materialism is Covetousness: Covetousness is a fact which the parable of the Rich-Barn-Builder revealed. Because love for material possessions leads to self-centredness, and the neglect of the poor/those in need, this parable therefore teaches Nigerian Christians this fact. A part of the problem of the Rich BarnBuilder as the exegesis indicated, was his self-centredness since he did not want

See K. I. Uwaegbute "A Critical Analysis of Causes of Moral Decadence in Contemporary Nigerian Christianity" Retrieved from http: //www.academia.edu/4660/67/A CRITICAL ANALYSIS -OF-CONTEMPORARY-NIGERIAN-SOCIETY CHRISTIANITY ON 20/10/2016. 
to share his rich yield with others around him. This is part of what is in vogue in Nigerian Christianity today whereby some church leaders amass material wealth at the expense of the poor members of the church. Worst still, most times, these poor Nigerian Christians are left uncared for by the same church leaders who they had contributed towards their earthly riches. In this regard, the parable warns Nigeria Christians against covetousness through quest for material possessions.

ii. Materialism wanes interest in God: As the exegesis indicated, care for material possession run contrary to interest in God. In other words it is an enemy of interest in God. This is a fact which plays out contemporarily in Nigerian Christianity whereby materialism has become, partly, an end in itself. In this situation, there is a strong shift in true interest in God and true spirituality. The quest for material possessions has even led some Christians in Nigeria very far away from God.

This, to some extent, has led to the decline of true spirituality in which things of God have been relegated at the expense of material possessions.

This parable of the Rich Barn-Builder therefore warns Nigerian Christians, in the strongest terms, that materialism conflicts with interest in God.

iii. True Christian Life Does not Depend on Material Possessions: One lesson Nigerian Christians have to learn from the parable of the Rich Barn-Builder is that true Christianity cannot be measured by material possessions.There is more to true Christianity, the parable teaches. This is aligned with the two points discussed above which tells the fact that true Christianity encompasses being rich towards God through sharing of wealth and possessions in service of God and humanity. In this regard, Nigerian Christians are to learn from this parable that true Christian life can never be measured by the amount of possessions one has.

iv. The Issue of Eschatology: God's judgment, which may come unexpectedly, is also part of the teachings of the parable of the Rich Barn-Builder. Even wealth and material possession could not save the Rich Barn-Builder from an unexpected death. So Nigerian Christians are warned of the fact that, in the midst of false security which possessions and wealthy may offer, death may come any time. This reveals the fact that Christian lives cannot be secured by earthly possessions.

In alignment with these lessons, the researchers therefore call for a strong deemphasis of materialistic view of Christianity dominant today in Nigerian Christianity by church leaders and theologians through balanced biblical interpretation of texts dealing with issues of wealth especially in the New Testament. Although we are aware of the strong connection between economic hardships, lack and the problem of materialism in Nigerian Christianity presently, Christians should be mindful of the illusionary security of human life which trust in material possessions gives. Hence the need to trust strongly in God for the provision for daily needs instead of amassing earthly possessions which end up swaying Christians' interest in God. 


\section{Conclusion}

The parable of the Rich Barn-Builder in Luke 12: 13-21 denounces, in strongest terms, too much interest in material/ earthly possessions by Christians since such conflicts with interest in God. In contemporary Nigerian Christianity it was shown in this study that the quest for material possessions has taken centre stage; there is excessive desire for material possession by Nigerian Christians and this has become a bane of true spirituality in contemporary Nigerian Christianity. Hence the parable of the rich barn-builder in Luke 12:13-21, which de-emphasizes quest for material possession, provided an interpretative framework with which the researchers addressed the issue of materialism in present Nigerian Christianity. Therefore Nigerian Christians are strongly warned by the teaching of the parable about the dangers that lay in using materialism as a matrix for measuring one's worth before God. In other words, Nigerian Christians are taught by this parable that true spirituality is not dependent on how much one possesses.

\section{References}

Achunike, H.C 2004. The influence of Pentecostalism on Catholic Priests .Onitsha: African First Publishers

Alland K . et al.1993. The Greek New Testament. (with Dictionary) Stuttgart: Deutsche Bibelgesllschaft

Aweda, S. 2009. 'A highly Religious Nation in Crisis of moral Decadence: Probable cause (part

1)" Retrieved from http://www.nairarules.com/religion-philosophy-spirituality/29/25highly-religious-nation on 10/10/2016

Brown, R. E. 2014. An Introduction to the New Testament. Banglore: Theological Publications

Bultmann, R. 1963. The History of Synoptic Tradition. Oxford: Basil Black Well.

Chinwokwu. E. N. 2015. A Critical Introduction to the Traditions ofJesus. Nsukka: UNN Press

De Silva , D.2004. An Introduction to the New Testament, Contexts, Methods and Ministry Illinois:Intervarsity

Egbujo, U. 2015 "The Worldly Church of a 'Religious' Society” The Vanguard. Retrieved from http://www.vanguardngr.com/2015/03/the -worldly-church-of-a-religious-society/on 15/10/2016

Esler, P.F. 1987. Community and Gospel in Luke - Acts Cambridge: Cambridge University Press

Goerman, M.J. 2006. Elements of Biblical Exegesis. Massachusetts: Hendrickson, 2008.

Gowler, D. 2006. 'The Context of Jesus' parables” Retrieved from http://www.baylor.edu/ifL/ Christian reflection/ Parables Article Gowler . Pdf on 20/10/16

Grant, F.C 1973. The Economic background of the gospel Oxford: Oxford University Press, 1 Isaak P.J .2006. 'Luke’ Africa Bible Commentary. Nairobi: Word Alive, 2006 
Johnson L.T, 1981. Sharing Possessions. Philadelphia: Fortress

Jeremias, J. 1969. Jerusalem during the Time ofJesus. London: SCM Press

Karris R.J 2000.'The Gospel according to Luke' in R.E. Brown; J. A. Fitzmeyer and R. E.

Murphy (eds)The New Jerome Biblical Commentary New Jersey: Prentice Hall Moorman, R.J.H.1961. The Path to Glory. London: SPCK

Minchakpu, 0. 1999. 'Materialism, Heresy Plague Churches' Christianity Today, May 24.

Ngong D.T 2009 "Salvation and materialism in African Theology" Studies in World

Christianity Vol 15, Issue 1,1-21

Obiora, F.K.1998. Divine Deceit: Business in Religion. Onitsha: Optima Publisher

Onwu E.N 2006."Poverty and Prosperity in Nigeria Pentecostal Theology: A New

Testament critique" Journal of New Testament Research, Vol.I 2006

Pilgrim, W.E. 1981. Good News to the poor: Wealth and Poverty in Luke-Acts Minneapolis: Ausburg

Poter L. 1988.'Luke' International bible Commentary. F.F. Bruce (ed) Michigan: Zondervan

Taylor, V. 1988. Formation of Synoptic Tradition. London: MacmillanKarris R.J 2000.'The Gospel according to Luke' in R.E. Brown; J. A. Fitzmeyer and R. E.

Taylor, V. 1988.Formation of Synoptic Tradition.London: Macmillan 